\title{
When Modernism Was Still Radical: The Design Laboratory and the Cultural Politics of Depression-Era America
}

\section{Shannan Clark}

December 2, 1935, dawned frigid and blustery in New York City as the metropolis endured an Arctic blast that heralded the arrival of winter, but several hundred young men and women lined up early nonetheless outside the East Thirty-ninth Street office of the Works Progress Administration (WPA). Although queues like this one had become commonplace in the midst of the Great Depression, those waiting in the morning chill sought not employment on a WPA infrastructure project but a chance to enroll in the Design Laboratory, a pioneering new school sponsored by the Federal Art Project (FAP), one of the WPA cultural programs. As the first institution in the United States to offer comprehensive education in modernist design, its introductory brochure claimed that it had been "created to supply a hitherto unfulfilled and pressing need in America" for people with the skills to devise, package, and promote consumer products that were styled to sell, thereby stimulating economic recovery. By emphasizing "coordination in the study of esthetics, industrial products, machine fabrication and merchandising," the school would "train designers, not specialized craftsmen, by correlating thorough instruction in the general principles of design and fine arts with shop practice."' The line of young adults on the first day overwhelmed the registrar. The Design Laboratory enrolled 220 students - which was somewhat more than the school's administrators had anticipated — and still had hundreds more on a waiting list to enter should space become available. ${ }^{2}$

The Design Laboratory had significance far beyond that of just a school for commercial artists. It furnished a vibrant point of contact between the business culture 
of America's industrial design entrepreneurs, the experimental modernism of the depression-era avant-garde, the unprecedented public arts bureaucracy of the New Deal, the militant industrial unionism of the Congress of Industrial Organizations (CIO), and the radical cultural politics of the Popular Front. ${ }^{3}$ When its federal funding stopped in June 1937 as part of a general retrenchment in the WPA cultural projects, the faculty and students reorganized the Design Laboratory under the sponsorship of the Federation of Architects, Engineers, Chemists and Technicians (FAECT), one of the left-led unions of white-collar workers affiliated with the CIO. After the union was compelled to withdraw its backing the following summer, the school experienced a second reorganization to become an independent cooperative officially chartered as the Laboratory School of Industrial Design. As it evolved from a provisional experiment in art education supported by temporary relief measures, attaining some measure of permanence as an academic institution, the New York State Board of Regents authorized it to confer bachelors degrees. Unfortunately, the dedication and effort of the laboratory's faculty, students, and advocates could not overcome both the school's perennially shaky finances and the turbulent political and cultural currents that accompanied the Second World War. The school suspended its regular operations at the end of 1939 and permanently disbanded in the spring of 1940, scattering its faculty and students throughout the design profession.

Although the Design Laboratory lasted only four years, it had a substantial influence on American visual and material culture. Perhaps its most immediately apparent impact came through the pedagogical and curricular innovations of its faculty. Through the first half of the 1930s, the art and architecture programs at most elite schools were still defined by the anachronistic Beaux Arts traditions of the late-nineteenth century, while the earliest courses in industrial design offered by commercially oriented art and technical schools like Pratt Institute in Brooklyn tended to be, in the words of laboratory alumnus Don Wallance, "mainly superficial and anecdotal." By the late 1940s, however, the modernist aesthetics and the instructional approaches developed at the Laboratory had become the new standard throughout the United States, as, in many cases, artists and designers who had been associated with the school joined the faculties of other academic institutions, bringing the Laboratory's pedagogy and curriculum with them. On a more fundamental level, however, the Design Laboratory was not merely a dispensary of useful knowledge about cutting-edge styles and techniques; it was also a site where practicing and aspiring designers and artists engaged with administrators, entrepreneurs, union organizers, critics, curators, and journalists to negotiate the social meanings and ideological connotations of American modernism. The initial germination of modernist aesthetics in the visual arts had been closely linked with the radical movements of the Progressive Era, whose partisans, like the painter and illustrator John Sloan, hoped to use new modes of representation to provoke sweeping political and social transformations. ${ }^{5}$ By the 1920 s, businesses also gradually began to lay claim to modernism in order to evoke not revolutionary possibilities but instead evolutionary progress and prosperity under capitalist auspices. ${ }^{6}$ Eventually, key cultural elites embraced modernism as well, as evidenced by the founding of the Museum of Modern Art (MoMA) in New York City in 1929.7 
The protracted crisis of the Depression intensified this ongoing contest over modernism by sparking renewed debate over the control of the means of cultural production. Plummeting consumer demand pressed manufacturers and merchants to place greater emphasis on product differentiation strategies, such as enhanced styling, in order to bolster sales and build market share. In response, artistic entrepreneurs such as Raymond Loewy, Norman Bel Geddes, and Henry Dreyfuss gained acclaim as practitioners of the new profession of "industrial designers." During the 1930s, they popularized a streamlined vision of modernity in their prolific commissions for packaging, durable consumer goods such as home appliances and automobiles, retail interiors, passenger trains, roadside commercial architecture, and the futuristic "world of tomorrow" under corporate auspices displayed at the 1939 New York World's Fair. ${ }^{8}$ Despite the hype surrounding the fledgling profession of industrial design, however, streamlining could not overcome the persistence of chronic unemployment and paltry wages; in fact, the success of the field's leaders could not even come close to providing work for all those who sought jobs in design and the applied visual arts. Subsequently quite a few designers, educators, cultural commentators, and consumer activists resisted the efforts by business interests to dominate the representation of modernity. Some of them objected to what they saw as the waste inherent in streamlining products, which required the use of unnecessary materials, inflated prices, concealed defects, and fostered artificial obsolescence. ${ }^{9}$ Other critics of streamlining believed that its superficial appearance of organic unity obfuscated the labor involved in the creation and use of goods, or that it thwarted the development of a modernist aesthetic influenced by the simple utilitarianism evident in many of America's vernacular design traditions. Still others, who asserted themselves as elite arbiters of taste, desired a refined modernism distinct from the crass vulgarity of streamlining. ${ }^{10}$

The Design Laboratory thus furnished an important setting for those dedicated to the promotion and development of a wide range of modernist styles, in considerable part because it operated largely outside the existing institutional frameworks of corporate cultural production. The school was a prime example of the alternative institutions for cultural production - sponsored either by government, labor unions, or cooperatives - that many radical and progressive artists, designers, writers, performers, educators, and consumer activists sought to establish during the 1930s and 1940s. Protests by these disaffected members of the creative class had helped to persuade federal officials to include the four cultural projects for art, writing, music, and theater as key elements of the WPA, and the supporters of these projects - including the Design Laboratory's faculty and students - pushed hard for these relief endeavors to be made permanent. Members of the creative class also organized militant unions like the one that rescued the school when the WPA discontinued its funding. These unions sought not only to improve the terms and conditions of employment for those in the culture industries, but also to secure greater opportunities for creative autonomy and, most ambitiously, to transform America's culture of consumer capitalism. Although the Laboratory commenced with an eclectic approach to modernist aesthetics, the majority of its faculty and students eventually came to favor functionalist approaches to modernism and to eschew streamlining. Some of them even hoped that their functional- 
ism could serve as a distinctive aesthetic for the production and distribution of goods and services by the public sector, cooperatives, or unions, much as the streamlining of the industrial design entrepreneurs had effectively become the style of consumer capitalism in the United States at mid-century.

While the Design Laboratory exemplified the democratic promise inherent in so many of the cultural endeavors launched by radical and progressive activists during the 1930s and 1940s, the school's history also demonstrates the obstacles to the establishment of enduring alternative institutions. Many of the Laboratory's faculty, students, and other advocates soon found themselves at odds with administrators in the Federal Art Project over the school's primary purpose. FAP National Director Holger Cahill and many of his associates believed that the Laboratory should promote an approach to representing modernity that was rooted firmly in American vernacular design and folk art traditions as it trained FAP staff for assignments to cultural extension programs in the hinterlands. Cahill and other FAP administrators gradually withdrew their support as the school's day-to-day operations increasingly diverged from their initial objectives, instead channeling additional resources into efforts like the Index of American Design, which documented "antique" vernacular material and visual culture from around the country. Left-led unions of cultural workers like the FAECT proved to be far more ideologically compatible sponsors for the school, but the radical and progressive forces in the labor movement frequently lacked the resources to sustain such cultural endeavors. In addition to the problem of patronage, the Laboratory's advocates also encountered resistance in their attempts to define functionalist modernism as a signifier of social democracy. Although the school benefited from some of its collaborations with institutions like MoMA, the efforts of a growing number of cultural elites to construct a functionalist "International Style" of sophisticated modernism that connoted refined status rather than affinity for the radical and progressive social movements of the 1930s and 1940s tended in general to subvert the laboratory's cultural politics. Lastly, the Nazi-Soviet Pact of August 1939 disrupted the alliances and collaborations of the Popular Front, pitting communist stalwarts and sympathizers against anti-Stalinist radicals and progressives, and making the fundraising miracles that kept the laboratory's doors open ultimately too difficult to perform.

The evanescence of cultural initiatives like the Design Laboratory — decades ago in a moment when modernism was still radical - reminds us that neither the aesthetic evolution of the material and visual culture of the modern United States, nor the renewed hegemony of consumer capitalism in the wake of the Great Depression, were inevitable processes with teleological outcomes. Instead of a surfeit of streamlined goods manufactured by corporate manufacturers for the mass market and a small niche market of tasteful but pricey functionalist goods for distinctive upscale consumers, other options were possible in the mid-twentieth century. In light of the challenges of our own time, as Americans grapple with the necessity of ecological sustainability and the various ramifications of the economic crisis of the early twenty-first century, the Design Laboratory appears not as a quaint relic but rather as a useful example of paths that can still be taken to promote democratic alternatives to the prevailing variants of consumer capitalism. 
The Design Laboratory owed its birth to the confluence of social and political forces that compelled the Roosevelt administration and Congress to experiment with the public provisioning of goods and services during the depths of the Depression. But while the protests by the militant organizations of artists, writers, and other cultural workers for relief employment, along with the lobbying by progressive educators, curators, and critics, compelled the government to include the FAP within the larger WPA, only the interest of Holger Cahill and his associates accounted for the specific decision to include a school for modernist design in the wide array of FAP activities in New York City. WPA Director Harry Hopkins had selected Cahill as the ideal candidate to head the FAP because of his tireless efforts to promote a wide range of artistic forms and styles, and his extensive personal connections with artists, critics, and patrons of diverse aesthetic and political convictions. From 1922 to 1931, Cahill had worked under the progressive curator John Cotton Dana at the Newark Museum, and in 1932 he joined the nascent Museum of Modern Art as its director of exhibitions. The Design Laboratory concept appealed to Cahill as a way of furthering his support for both modernist experimentation and a heightened appreciation of folk art and vernacular design traditions. Furthermore, he hoped that the school could contribute significantly to the FAP's primary mission of democratizing American culture by creating new opportunities for people to experience art in their everyday lives. As he saw it, the purpose of industrial design was "to enrich and make beautiful the common articles of daily use," thereby making art "no longer the precious possession of the chosen few" but rather "a necessity for the many." Although he claimed that "no institution so "unfits' students for work in the world as the traditional art school," rooted as it was in the "theory of the "unique and precious' in art," Cahill maintained that the laboratory, by contrast, would give the artist "an opportunity to relate his talents to wider fields of usefulness."

Frances Pollak, whom Cahill hired to supervise all FAP educational programs in New York City, assumed the responsibility of recruiting a director and an advisory board to provide nominal oversight for the school and give it legitimacy. Successful industrial design entrepreneurs such as Loewy, Walter Dorwin Teague, Donald Deskey, George Sakier, and Russel Wright agreed to lend their prestige to the Design Laboratory by serving on the advisory board. Progressive architects like William Lescaze, Percival Goodman, Harvey Wiley Corbett, and Ely Jacques Kahn also enlisted as advisors, as did the curator and educator Richard Bach of the Metropolitan Museum of Art. Editors of trade publications, such as Alfred Auerbach of Retailing and Earl Lougee of Modern Plastics, joined as well. Some of the more progressive members of the advisory board, including Bach, Goodman, and Lescaze, periodically gave special guest lectures at the school, but the bulk of them - including, significantly, the most commercially oriented of the industrial design entrepreneurs - did little more for the school than let their names appear on its early publicity materials. For the position of director, Pollak lured furniture designer Gilbert Rohde, whose studio created numerous pieces for the Kroehler and Herman Miller furniture companies during the 1930s. ${ }^{12}$

The prospectus for the school that Pollak prepared for Cahill reflected the thorough influence of progressive social theory, pedagogy, and design. Her comprehensive bibli- 
ography featured major texts by social theorists and scholars like John Dewey, Charles Beard, and Lewis Mumford along with writings by important modernist architects and designers such as Frank Lloyd Wright, Laszlo Moholy-Nagy, and Le Corbusier. Yet in Pollak's estimation, one work on the list, Thorstein Veblen's Theory of the Leisure Class (1899), loomed in importance above the rest. By explaining particular types of cultural expression as manifestations of various stages of social and economic development, Veblen provided a crucial ideological basis for functionalism as the legitimate aesthetic for the machine age. The flaunting by modern elites of outmoded signifiers of status from the distant past indicated in no way, Veblen maintained, how their power actually rested in their control over the most thoroughly rationalized and technologically advanced industrial enterprises in the world. Emulated by subordinate social groups through "conspicuous consumption," the ostentatious practices of the leisure class became pervasive obstacles to rational cultural progress that served to "lower the industrial efficiency of the community and retard the adaptation of human nature to the exigencies of modern industrial life." Consumer goods, Veblen lamented, rarely could "pass muster on the strength of material sufficiency alone," but instead had to show the "honorific element." Even the rustic simplicity of the Arts and Crafts movement inspired by William Morris and propagated in America by figures like Gustav Stickley seemed to Veblen nothing but a disingenuous "exaltation of the defective" in an era defined by the proliferation of inexpensive standardized goods. The craft revivalists' "sophisticated archaism," Veblen noted in a 1902 article, ran counter to "the requirements of modern business enterprise as well as of modern, that is to say democratic, culture." Any effort "for the reform of industrial art or for the inculcation of aesthetic ideals must fall in line with the technological exigencies of the machine process," he maintained, if it were to have a chance of "checking the current ugliness" he found in much of the period's design. ${ }^{13}$

Drawing upon both Veblen's analysis of conspicuous consumption and the democratizing impulses of progressive educational reformers like Dewey, Lewis Mumford's aesthetic critiques also provided a key inspiration for the school. Mumford was at the height of his influence during the 1930s, and Design Laboratory instructors routinely assigned his texts to their pupils. The progressive sensibility, he wrote in his magisterial survey Technics and Civilization (1934), had revealed the potential to liberate "forces which were suppressed or perverted by the earlier development of the machine." But while advances in technology and culture hinted at the promise of a modernist future, Mumford bemoaned that it existed "only in fragments." Evidence of the Gilded Age penchant for misapplying outmoded decoration to the products of industrial technology still abounded, while the "frantic attempts that have been made in America by advertising agencies and 'designers' to stylicize machine-made objects" perverted "the machine process in the interests of caste and pecuniary distinction." Functionalist aesthetics, rather than the expressive modern ornament of streamlined industrial design, evoked the emerging ethos of "conspicuous economy" that Mumford believed was appropriate for a mature society characterized by "dynamic equilibrium" rather than unregulated growth and cycles of industrial boom and bust. ${ }^{14}$ 
Despite the stringent budgetary restrictions imposed on all of the WPA cultural projects, which mandated relief salaries of approximately $\$ 30$ per week for the majority of instructional employees, Pollak succeeded in attracting a diverse core of talented young designers and artists to teach at the Laboratory. Some, like interior designers Hilde Reiss and William Priestly, and graphic designer Lila Ulrich, had studied in Germany at the Bauhaus before the Nazis closed the legendary school of modern design in 1933. A few members of the Laboratory faculty, like product design instructor Jacques Levy, held degrees from elite American universities like Columbia and Yale. But the majority of the instructors, including product designers William Friedman and Joseph J. Roberto, painters Irene Rice Pereira and Jack Kufeld, and sculptor Chaim Gross, had patched together their training from a combination of coursework in art, architecture, or engineering at more plebian local institutions like City College, NYU, Cooper Union, Pratt Institute, and the Art Students' League. For most of them, the pedagogy that they developed grew principally out of their workplace experiences and independent exposure to modernist styles, rather than from their own time in the classroom as pupils. For the instructors nearly as much as the students, the daily activities at the Laboratory were a pragmatist exercise in "learning by doing." The faculty stressed creativity and proficiency in a wide range of media and techniques. They encouraged students to transcend staid boundaries between disciplines, and to integrate multiple design skills so they could meet the changing needs of industry. In place of "the existing artificial distinction between interior decoration and designing of mechanical objects," according to the initial bulletin, classes at the Laboratory were "grouped according to present day trends in fabrication and design. In this manner, wood, metal and plastics are treated as a unit." Likewise, "designs for lipstick cases and automobiles may be included in one course, for materials, tools and even design are similar." ${ }^{\prime 15}$

From the day its doors opened, FAP administrators and consultants imagined the Design Laboratory as an integral component of their ambitious plans to democratize American culture. Faced with the daunting task of staffing local programs in remote parts of the country, Cahill hoped that the Design Laboratory would furnish a reliable source of competent personnel. In one November 1935 memorandum, he explained that the school's purpose was not just to meet "the increasing demand of industry for designers," but also "to train teachers working on our projects" as well as to provide for the "rehabilitation and retraining of artists, teachers and craftsmen who have been displaced through the development of modern technology." Several months later, while assisting with the preparation of materials on the early accomplishments of FAP to be presented to Hopkins and First Lady Eleanor Roosevelt, Cahill emphasized personnel training even further, describing the laboratory as a "master teaching project" to prepare instructors who could then "take the ideas and methods they have received in the Design Laboratory to hundreds of adult and youth groups under the FAP and the WPA Recreation Division." 16

These schemes reflected not just the logistical challenges confronting Cahill and his top associates, but also their own aesthetic and political sensibilities. This was perhaps most evident in the early relationship between the Design Laboratory and the 
Index of American Design, which eventually became the best-known FAP initiative in the field of material culture. Spearheaded by Pollak, acclaimed textiles designer Ruth Reeves, painter Romana Javitz, and cultural historian Constance Rourke, the Index hired hundreds of artists to produce renderings, primarily watercolors, of a wide array of decorative and applied arts, ranging from implements like weather vanes, to household goods like toys and quilts, to furniture. Unlike the antiquarian and antimodernist enthusiasts of colonial revivalism such as Wallace Nutting, who sought retreat in the American past, proponents of the Index envisioned the seventeenth-, eighteenth-, and nineteenth-century artifacts documented by the project as the legitimate precursors of a distinctly American modernism. They hoped that the Index and the Laboratory would complement each other in the promotion a democratic cultural sensibility that was both nationalist and forward-looking. In early 1936, Cahill extolled the potential of the Laboratory as a center for design innovation while also conceiving its mission as fundamentally linked to the efforts of the Index to document and make available to new generations of Americans the vernacular design traditions of the nation's past. In a letter to New York Times art critic Henry Brock, Cahill portrayed the Index as "a continuation of the work of the Design Laboratory." Elaborating shortly afterward in a public report on the early progress of the FAP, Cahill described the Index as "allied" to the Laboratory, and claimed that the documentary initiative was "a project of incalculable importance to American manufacturers, scholars, and creative artists in the field of design." By placing "at the disposal for everyone interested in the field of American decorative and applied art, for the first time, a graphic record of the development of American design," the Index provided grounding for the Laboratory's modernist experimentation. ${ }^{17}$

Throughout the first half of 1936, FAP administrators continued to discuss a variety of proposals to employ both the pupils and faculty of the Laboratory in far-flung extension programs. After learning of a vocational workshop in Massachusetts that was idle in summer months, Cahill proposed using it as a base for a small detachment from the Laboratory that "would inaugurate a program for re-training New England craftsmen." Reeves, who traveled the country as a consultant for the FAP, suggested linking the Design Laboratory with the regional efforts of the Recreation Division, the National Youth Administration, and the Civilian Conservation Corps. Although she had successfully incorporated traditional Guatemalan motifs in her own textile designs and was one of the staunchest champions of the index, Reeves was also critical of the shortcomings of much folk production. Appalled "at the lack of taste and general gimcrackeryness" of the crafts programs she surveyed on a field visit to South Carolina, she suggested that the Laboratory could furnish personnel with a "socially creative point of view" to establish progressive craft activities in rural areas. Such a move would also alleviate what she characterized as the "congestion" affecting the FAP programs in New York City. Using the Laboratory in cooperation with other federal agencies as part of a comprehensive system of newly available public goods and services, she hoped, would legitimate the FAP "in a popular way at least as it has never been justified before." None of these proposals, however, were realized, and by the end of the year discussion of Laboratory extension projects largely ceased. As 
it became increasingly evident to Cahill that it was not going to become a significant source of staffing for other FAP activities, his early enthusiasm for the school waned. ${ }^{18}$

Much to the dismay of Cahill and Reeves, most of the Laboratory's faculty and students resisted attempts to subordinate the school to the needs of the Index or distant vocational, educational, or exhibition programs. Although the emphasis on improvisation and experimentation drew positive attention to the school, it also reflected the problem of developing a systematic curriculum, with a logical sequence of assignments over multiple semesters, in the absence of permanent funding. Nonetheless, in August 1936 the Laboratory implemented a provisional three-year design curriculum. "It has been plain that an educational organization," the New York FAP office proclaimed in a press release, "founded to provide instruction in the best modern design, could not operate on a purely temporary basis." In the new Laboratory course of study, however, students would really be able to "learn by designing a clock, a chair, a table, an inkwell, an ashtray, a radio cabinet, an interior of a house; by drafting blue prints, and then by actually carrying out the design, either life-size or to scale in model." Such an approach was "no new principle in progressive education," but it nonetheless remained a novelty "when applied to industrial design." While the school remained the only one in the United States "to present in a coordinated fashion the standards of taste and style evolved elsewhere in the world in the so-called 'International Style'," its intention was not "to hand down dogmas about functionalism and modern design." Just because "Le Corbusier has made extremely handsome chairs of chromium-plated tubing on which bands of textiles hang in the perfect suspension," for example, modern designers "need not reject wood as a basic material for a chair." The early student work documented by the FAP (see Figures 1 and 2) shows the combined influence of the Laboratory's design philosophy, its gradually coalescing curriculum, and its limited resources. The frequent selection of wood as a material expressed an affinity for a modernism that functionally evolved from vernacular design traditions, but also reflected the comparatively low cost of wood and the accessibility of woodworking tools. Likewise, while the cigarette cases in Figure 1 illustrate a sleek functionality, several of the clocks in Figure 2 reveal an expressive representation of modernity that cut against the school's increasing emphasis over time on function over ornament. ${ }^{19}$

The FAP portrayed the Design Laboratory's version of modernism as an improvement on the International Style, based on pragmatist experimentation and genuine functionality rather than slavish imitation, while also distinguishing the school's approach from that of the leading industrial design entrepreneurs. Ironically, Pollak's office chose Rohde, who personified the school's tenuous connections to the commercial design business, to convey this message. Rohde had limited involvement in the daily operation of the school, instead preferring to focus on the more lucrative task of running his own agency. He had benefited from the popular hype surrounding the young profession of industrial design, and his appointment as director was an effort to appropriate some of that buzz to help legitimate the school. Yet the essay in the October 1936 issue of Magazine of Art signed by Rohde, but based on publicity copy probably written for the FAP by art historian and critic Elizabeth McCausland, set out to deflate the celebrity image of the industrial design entrepreneurs. "Certain 


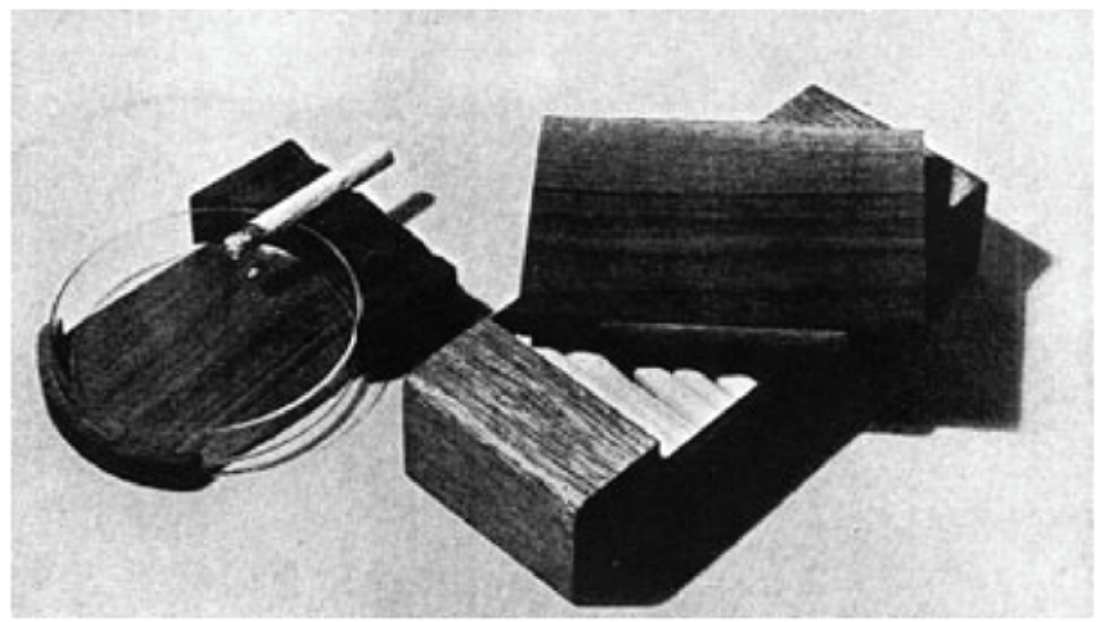

Figure 1: Cigarette box and ashtray set designed by unknown Laboratory students, 1936. (Courtesy of the Archives of American Art.)

magazine articles, calculated to 'dramatize' a new profession," he claimed, had portrayed industrial design "as being the exclusive and mysterious possession of a handful of super-men who are revolutionizing everything from hairpins to locomotives at a fabulous price." By contrast, the Laboratory unlocked the "impulse to create" latent in all human beings. What mattered was not "whether the perfect solution was found for all the elements of fabrication, material, price, function, salability, and aesthetic concept" but that "every one of these elements was consciously considered by the student." At the Design Laboratory, he contended, "clock cases into which works cannot be inserted do not pass into the model stage," while "ash trays that tip too easily, or boxes that can be made only by sleight-of-hand, never get off the drawing board." 20

William Friedman, who taught product design at the Laboratory, offered a much more pointed assessment of the relationship between the school's pedagogy, functionalist aesthetics, and the actual practice of design for mass production in a critical review of Nikolaus Pevsner's influential Enquiry into Industrial Art in England. "The products of present-day technological enterprises," Friedman noted, "are not designed by a handful of individuals" as both the streamlining industrial design entrepreneurs and the acolytes of the International Style masters frequently insinuated. Instead, the appearance of mass-produced goods resulted cumulatively from the unacknowledged labor of "thousands of unknown draftsmen" and "tool and die designers and makers" in factories who found "no romance in the process of designing, because designing is a hard-boiled proposition in which the designer is told what to design by the salesmen and the buyers." Aside from a few carefully culled examples, Friedman complained, "one looks in vain for further substantiation of Pevsner's thesis" that "good design pays" for the manufacturer. Improving the quality of the built environment and of material culture involved not the formalistic imitation of functionality celebrated by 


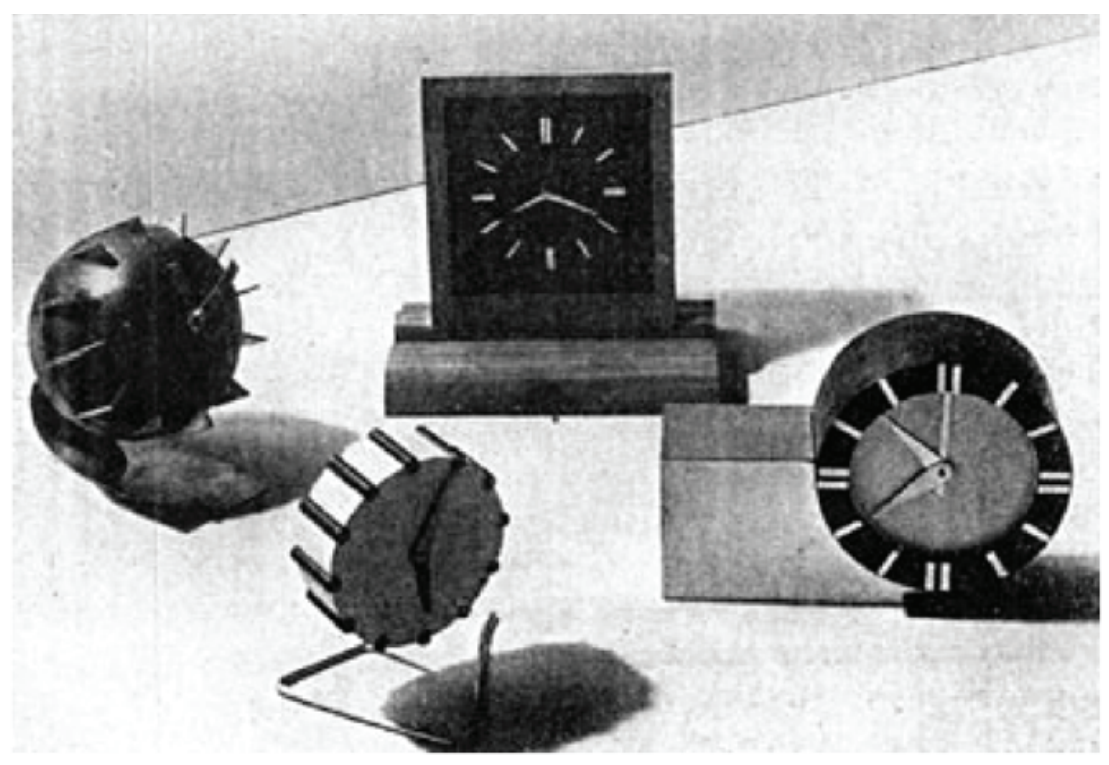

Figure 2: Clocks designed by unknown Laboratory students, 1936. (Courtesy of the Archives of American Art.)

Pevsner, but instead a multi-faceted approach directed at the roots of contemporary social and economic problems. "For the public," Friedman asserted, "the question of design taste will have to be treated along with the three R's, as part of the basic training of every citizen" rather than as "an esoteric item completely separated from the common experience of living." For designers themselves, the remedy was "a more realistic concept of the practice of design," fostered by schools like the laboratory, that helped them to understand that their creative mental labor was "just one part of the manufacturing process" and that they were "in no more exalted a position than the tool and die maker in the factory."21

In the development and implementation of the school's progressive approach to design, the Design Laboratory's proponents had predicated their analysis on a Veblenian understanding of consumption, but they took another cue from Veblen by heeding his cautionary remarks concerning the dynamics of power within modern educational institutions. In The Higher Learning in America (1918), he had attacked what he saw as the corporate domination of American colleges and universities for subverting the ideal of disinterested inquiry. Close association with business interests had a "corrupting influence on the scientists and scholars," inducing in them a "bias towards 'practical' results in their work" and a tendency to keep "more or less of an eye to the utilitarian main chance." Although it could be considered an institution dedicated to providing what Veblen had characterized as "matter-of-fact" technical knowledge, the Laboratory's faculty and students nonetheless aspired to cultivate an intellectual scope and critical perspective that transcended the limitations of 
bureaucratic instrumentalism. They supported public sponsorship as a matter of principle, and most lobbied for the establishment of a permanent art project, but they still rankled at the supervision of FAP administrators. Inevitably, their rebellious insistence on autonomy led to friction between the school and the government agency that sustained it. ${ }^{22}$

Like many white-collar WPA projects, the Design Laboratory seethed with unrest. Many faculty and students joined militant organizations of cultural workers committed to collective action. Some belonged to groups influenced by communists; others favored groups in which socialists or Trotskyists predominated. A diverse band of radicals and progressives, they nonetheless participated together in numerous demonstrations and strikes over issues such as the continuation of funding for the school, instructors' salaries, staffing levels, reductions in the cultural projects' quota of "non-relief" personnel, and disciplinary measures meted out by FAP administrators. Student publications endorsed the New York Artists Union, demanded the creation of a permanent art project, and called for "professionals" and "workers" alike to join together in a "United Front against War and Fascism." As the school became increasingly troublesome, Cahill and his deputies grew ever more pessimistic about the Laboratory. During the fall of 1936, several FAP administrators faulted Pollak and Joseph Marvel, who had been hired as an assistant director to supervise the school's daily operations, for alleged mismanagement without recognizing the obstacles that resulted from the agency's stinginess. After an especially disruptive wave of demonstrations in December 1936, during which many students and several instructors were arrested and Marvel was suspended for his outspoken support of the protests, the national FAP publicity office even declined to furnish inquiring journalists with already existing publicity copy on the Laboratory. When it became clear in the spring of 1937 that Congress was going to reduce appropriations for the WPA sharply, the Design Laboratory was designated as one of the many programs to be discontinued. ${ }^{23}$

While supporters of the school participated in yet another round of strikes and demonstrations to protest the layoffs, William Friedman scrambled to assemble a coordinating committee to assume direction of the school. Working with the communist faction among the students and faculty, Friedman's committee arranged for sponsorship by the Federation of Architects, Engineers, Chemists and Technicians, and in July 1937 the Design Laboratory relocated to a loft space just east of Union Square that was next door to the union's office. Friedman, who became Chairman of the Faculty, later recalled that "practically everyone who was on the original staff continued" because they believed in the Laboratory "over and beyond its connection with WPA. It became a very important school educationally and there was a feeling of tremendous involvement on the part of both students and staff." A committee comprised of representatives from the union, the faculty, and the student body assumed the administration of the school. Freedom from relief regulations opened new possibilities while it posed new challenges. The school could admit any interested and capable students regardless of economic means, but it also depended on a meager stream of tuition revenue to cover most of its expenses. Instructors received less regular pay by teaching for a labor cooperative, but were able to moonlight as freelance designers 
to supplement their incomes. And, while the Laboratory operated on an ostensibly "permanent" basis, it had the backing not of the enduring federal government but a scrappy, left-led union for professional and technical workers that was only four years old. ${ }^{24}$

The school committee quickly put its ideals into practice by revamping the curriculum. Beginning with the 1937 summer session, it instituted a compulsory Materials Laboratory course for all incoming students regardless of their major or prior training. Modeled in part after the Foundations course developed at the Bauhaus during the 1920s, the new course provided a more effective introduction to the school's interdisciplinary methods by compelling aspiring designers to experiment with a wide range of materials and shop techniques. The committee also inaugurated a two-semester Design Synthesis course intended to familiarize new students with the panoply of modernist styles and techniques as a way of teaching fresh approaches to the conceptualization of design tasks. In the fall, the committee extended the school's three-year program of study into a four-year design program comparable to the 120-credit hour B.A. and B.F.A. programs at standard colleges and universities. As part of the four-year curriculum, the committee mandated new requirements in social studies, including courses in American labor history, economic history, and the cultural ramifications of industrial modernity, "thus developing in the student an understanding of the meaning of social and industrial integration." With enrollments rising to a peak of 400 pupils, the school was not unrealistic in its hopes that it might be the cornerstone for a "labor university." 25

Moreover, the Laboratory also became more assertive in its efforts to politicize functionalist modernism. Its new course catalog included a declaration of principles that began with the assertion that "mass production, being dependent on mass consumption, necessitates designs to meet the social needs of the consumer." As a result, conscientious designers were to place "as little emphasis as possible on ornament," and to avoid "arbitrary" decorative elements that had "no genetic connection to the functional and mechanical properties of an object whose surfaces they adorn superficially." Rather, "fabrication for function produces forms which have an inherent quality revealing both material and purpose." Partisans of the school were quick to point out that these principles were not hollow cant. "The original Bauhaus," Elizabeth McCausland contended in an August 1937 article, "germinal as it was, suffered somewhat from the romantically individualistic self-expression of the men of genius who founded and conducted it." Their formalistic preoccupation with "style," she argued, had overshadowed the proper social objectives of modern design. The Laboratory, by contrast, belonged to "a later generation than the Bauhaus," one that "understands that the most beautiful architecture, design, and art is not built by the individual, but by the coordination of talents and technics of individuals within the containing envelope of social relations." While fawning acolytes of the International Style might appropriate "the outward form of the Bauhaus" and recapitulate the "intellectual errors" of its masters, McCausland insinuated that Laboratory designers appreciated that the question of whether "the men who man the machines are dissatisfied by reason of too long hours and too low wages," was as important a func- 


\section{DESIG N LABORATORY}

FORMERLY OF THE FEDERAL ART PROUECT, WPA 10 EAST 3TH STREET :I NEW YORK CITY

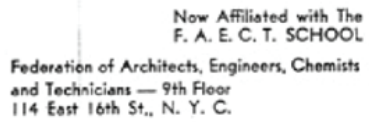

Now Affilisted with The F. A. E. C. T. SCHOOL Federation of Architects, Engineers, Chemists and Technicians - 9th Floor 114 East 16 th St.. N. Y. C

COURSES IN

INDUSTRIAL DESIGN

PRODUCT-TEXTILE-DISPLAY

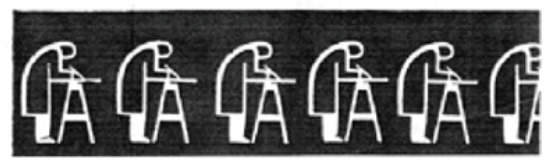

Figure 3: The Design Laboratory produced this brochure in the summer of 1937 to publicize its continuation after its federal funding had been eliminated. Note the designer-worker motif along the bottom. (Courtesy of Suzanne Sekey.) tional consideration as the selection of materials and fabrication methods. A new brochure for the Laboratory visually hinted at the school's social ideals with its motif of a design-worker than ran across the bottom edge of its cover (see Figure 3). Although there are fewer extant photographs of student designs from after the reorganization than from when the school was operated by the FAP, the majority of documented student designs from the period also reveal an increasing tendency to reject expressive or ornamental representations of modernity in favor of an austere functionalism. Don Wallance's stackable chair with a tubular metal frame and clear Lucite seat and back (see Figure 4), won an award from the Museum of Modern Art in late 1937 for its elegant simplicity. The student designs incorporated into a collage from the 1938 school catalog, including a mixer (see Figure 5), also were generally free of the chrome striping and other decoration typical on many of the appliances from the commercial-oriented industrial designers. ${ }^{26}$

As a cooperative venture, the Design Laboratory depended upon a dedicated community of faculty, students, and supporters actively engaged in the Popular Front movement culture that flourished in New York City during the late 1930s. Events like the school's August 1937 exhibition at the American Contemporary Artists' Gallery strengthened the affinities between the Laboratory's functionalist modernism and the broader cultural left. ${ }^{27}$ The school hosted lively rent parties, which instilled radical élan while contributing to its financial survival. To supplement its own offerings, the school encouraged students to take classes at the American Artists School sponsored by the leftist American Artists Congress. The school newspaper featured reviews of local art exhibitions and articles on shop methods alongside calls for aid to the embattled Spanish Republic and notices of boycotts against firms that resisted CIO organizing drives. One group of students and faculty met regularly during the fall of 1937 and the winter of 1938 to assist with various organizing campaigns being conducted by the FAECT and the other CIO unions for cultural workers. Students also lampooned the crass pretensions of the leading commercial designers, as Milton Kalish did in a scathing cartoon for the school paper (see Figure 6) that portrayed several students 

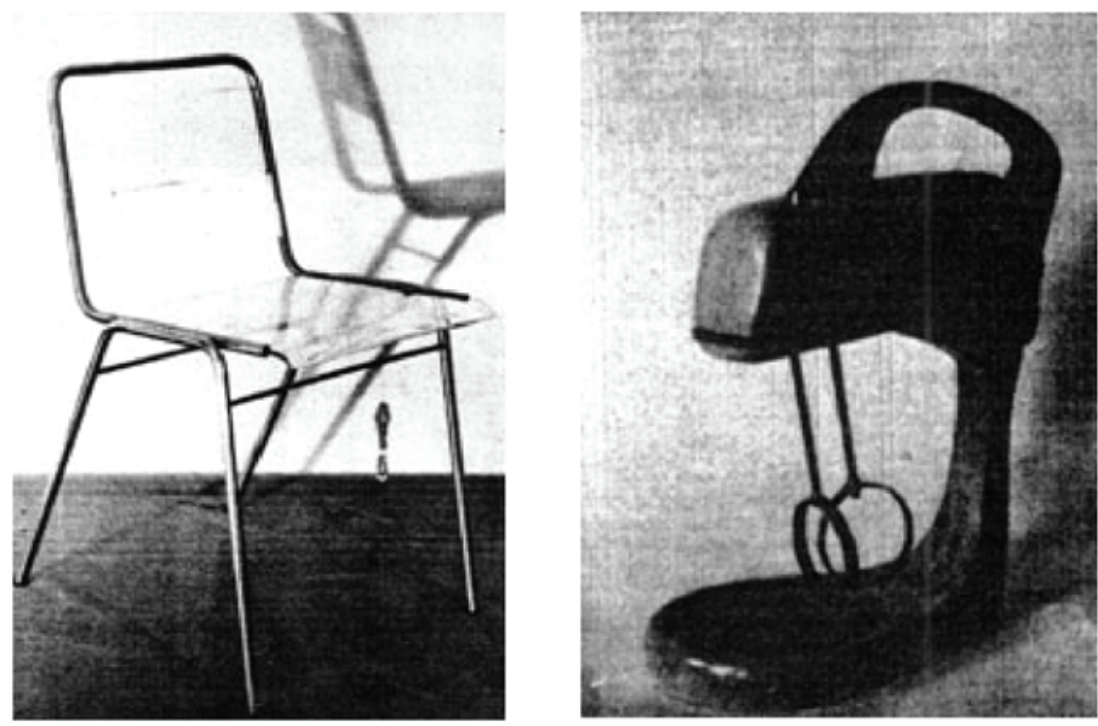

Figures 4 and 5: Laboratory student Don Wallance's chair with a tubular aluminum frame and Lucite seat and back won a 1937 design competition sponsored by MoMA. Both it and the blender designed by an unknown student demonstrate the school's functionalist aesthetic. (Courtesy of the Cooper-Hewitt National Design Museum.)

roasting a designer on a spit for defying functionalist tenets by "streamlining a coffee pot," a stationary object whose utility could not be enhanced through enhanced aerodynamics, while another student parodied the experimental method of the materials laboratory by jotting down his technical observations of the surrealist auto da fé. ${ }^{28}$

Still, the effort to forge a community of radical designers proved an arduous task. "We hear much about the progressive character of the Design Laboratory," a student wrote in a January 1938 editorial. "Such terms as 'student-faculty relations,' 'cooperation,' etc. have been heard so often that they are taken for granted by everyone." Yet there remained a "definite lack of understanding among students as to their role" in the school. "We must feel that we are not just isolated individuals attending classes and receiving instruction from teachers who have little in common with us, but that all of us are part of this cooperative scheme, with every phase of school activity of concern to each of us." Jacques Levy, who taught product design, concurred in an open letter, in which he combined a call for greater discipline with an appeal to the participatory values that informed the Laboratory. "Let us remember this: the school is no more important nor valuable to society than the students and teachers make it," he admonished. "Great things must be in store for a school with such principles as ours has. We're in at the beginning, a responsibility is ours-let's not muff it." ${ }^{29}$

In summer 1938, a confluence of factors resulted in the Laboratory ending its formal relationship with the FAECT. Although the union had significantly expanded its membership in private industry as part of the first major wave of CIO growth in 


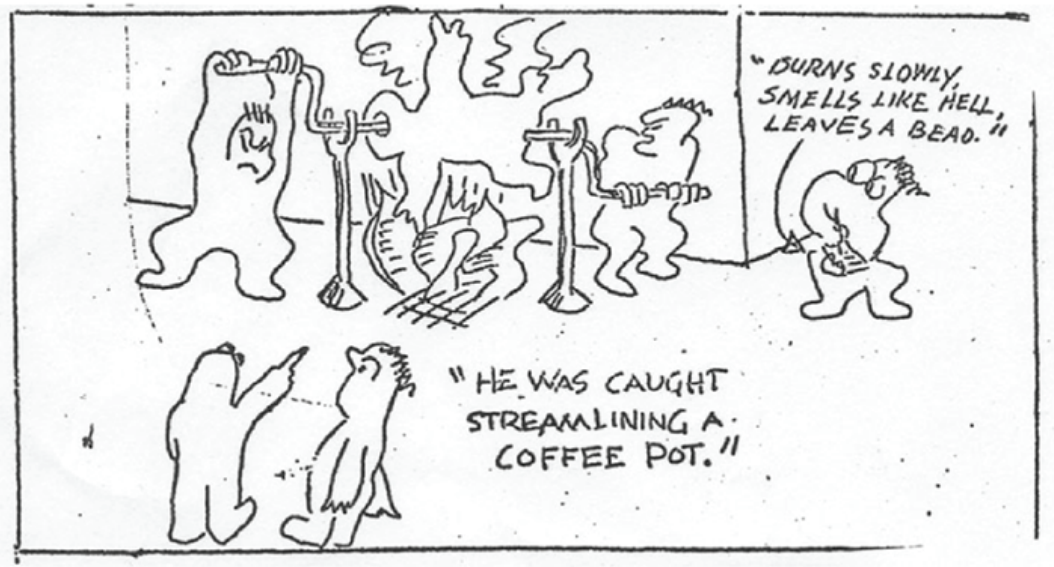

Figure 6: Cartoon by Milton Kalish from the school newspaper, 1938. (Courtesy of Suzanne Sekey.)

1937, like many of the insurgent industrial unions it struggled in 1938 to maintain its momentum in the face of recession conditions. Successive rounds of WPA cutbacks, meanwhile, reduced the membership, and thus the financial resources of the FAECT, through the layoffs of engineers, architects, and draftsmen previously employed on public works projects. Additionally, some on the school's committee began to fear that the Laboratory's links with the left-led union might jeopardize its quest for accreditation. Already, conservative New York state legislators and officials fulminated about the presence of communists in the educational system, and within a year the state's Rapp-Coudert committee purged numerous teachers from City College and the New York City public schools. Once the school was independent from the union and had changed its name to the Laboratory School of Industrial Design, it obtained a charter from the New York State Board of Regents that permitted it finally to confer degrees. Nonetheless, the school remained in its loft space near Union Square, and most of its faculty and students continued their participation in Popular Front activities. ${ }^{30}$

With no source of revenue other than tuition and donations, the Laboratory's financial situation remained shaky. Its 1938-39 catalog boasted that all instructors worked as designers in industry, giving them practical knowledge to pass on to their students, but in reality their inadequate teaching salaries made this a necessity. Levy, for example, freelanced for General Electric's home appliance styling division, wrote interior design guidelines for the New York City Housing Authority, and even worked on the elaborate dioramas that comprised Norman Bel Geddes' immensely popular Futurama exhibit for General Motors at the 1939 New York World's Fair. Nonetheless, the school made a number of new appointments in fall 1938 and winter 1939 that significantly enhanced the faculty. Some contributed additional experience with artistic method and theory, like sculptor and designer Theodore Roszak, Hungarian émigré painter Laszlo Matulay, and muralist Burgoyne Diller, who continued to serve 
with the FAP Mural Project after joining the school. Other new instructors brought experience from advertising, commercial design agencies, and the media. Industrial designer Peter Schladermundt had worked for Dreyfuss and Bel Geddes, while Danish architect and furniture designer Törben Muller had spent several years in Loewy's office. Harrison Murphy, a former art director at the Chicago Tribune, brought expertise integrating sales and marketing with the mechanics of print technology, and research chemist John Heasty, who had helped to lead a high-profile strike by whitecollar employees of Consumers' Research in 1935, drew upon his ongoing work at the progressive product testing institute Consumers Union as the basis for his courses in materials science. ${ }^{31}$

Two other additions to the faculty stood out in particular. One was Paul Rand, a graphic arts prodigy, who joined the school in the fall of 1938. At the age of twentythree he had become an art director for Esquire magazine and had won critical acclaim for the covers he designed for the leftist cultural review Direction. As a faculty member, Rand supervised the compilation and publication of A Design Students' Guide to the New York World's Fair in 1939. Although the same age as many of his students, he nonetheless commanded a degree of respect rarely accorded designers twice his age. The other addition was McCausland, who had done so much both under the FAP and afterwards to publicize and promote the school. Her new four-semester course on "Cultural Morphology," replacing the earlier required offerings in history and social science, correlated technological developments and changing class relations from the early eighteenth century onward with the rise of mass production and the eventual emergence of modernist aesthetics. In devising the course, she drew heavily upon the currents of progressive cultural materialism that informed the school, including the works of Veblen, Mumford, Charles and Mary Beard, and Robert and Helen Lynd. Yet her interest in the ways in which the meanings of mass-produced culture remained contested, her analysis of cultural production in terms of class, and her conviction that the study of culture should catalyze progressive social change, all foreshadowed the critiques of the trans-Atlantic early New Left, and the methodology of British Cultural Studies. In their own ways, Rand and McCausland each epitomized the dynamism of the Laboratory's radical modernist educational experiment. ${ }^{32}$

Attracting a top-notch faculty capable of establishing the Laboratory as a leading center of modernist aesthetics in the United States was in many respects less of a challenge than the efforts of the school's proponents to define functionalist modernism as a signifier of Popular Front social democracy. The ambiguous aesthetic strategies of the federal arts bureaucracy, the commercially oriented industrial design entrepreneurs, the labor movement, and the institutional network of elite patronage all influenced the evolution of ordinary Americans' understandings of various modernist styles in Depression-era America. In purely ideological terms the left wing of the labor movement was the obvious patron of choice for the laboratory, but it had a very limited capacity to secure the production or distribution of functionalist goods designed according to the Laboratory's principles. Moreover, the efforts of the left-wing unions were complicated by the efforts of key cultural elites to appropriate functionalist modernism as their chosen aesthetic strategy. Their common interest in promoting 
functionalist aesthetics, however, made them frequent collaborators, as each camp sought to use its partnership with the other to its own advantage.

Few events elucidated this contest over the connotations of functionalist modernism more poignantly than the retrospective exhibition on the Bauhaus that the Museum of Modern Art staged in December 1938. Held in exhibit space at Rockefeller Center while construction continued on its new permanent home on Fifty-third Street, the Bauhaus retrospective was the best-attended show thus far in the museum's history. In its own publicity efforts, MoMA sought to establish the artifacts of the disbanded Bauhaus as the kernel of a new canon of functionalist modern design. Besides featuring the sculptures, housewares, furniture, and architectural renderings of such Bauhaus luminaries as Walter Gropius, Ludwig Mies van der Rohe, and Marcel Breuer, the exhibition was also guest curated by former Bauhaus instructor Herbert Bayer, who had recently arrived on American shores as part of the wave of émigré creative talent fleeing Europe. The museum's Curator of Architecture and Industrial Art, John McAndrew, marveled in its Bulletin that so very few of the items exhibited "seem dated after a dozen years." Rather, reflecting the supposedly timeless tenets of modern design developed at the Bauhaus, "they were never meant to be 'in style' or 'the last word of 1926' but were honest and often distinguished." By contrast, McAndrew lambasted the streamlining evident in the work of industrial design entrepreneurs like Loewy, Dreyfuss, and Bel Geddes, charging that their aesthetic was not properly "modern," and assailing them for imitating "superficially the forms of modern art" and "reducing them to decorative mannerisms." McAndrew maintained that they engaged in "'restyling' almost everything, so that what we owned might look old fashioned as soon as possible," by seizing upon streamlined forms which were subsequently "misapplied" to a "fantastic variety of objects." The designs in the exhibition, however, "whether for chairs, lighting fixtures or ash trays," were "free of both modernistic and streamlined aberrations" since "sound Bauhaus training would not permit them." Within McAndrew's cultural hierarchy of taste, the high modernism of the Bauhaus was far superior to the prevailing streamlined representations of modernity that were proffered by the leading entrepreneurs of commercial industrial design. ${ }^{33}$

Tucked away in a corner of the exhibition, Bayer and his assistants on the MoMA staff included a small display of abstract sculptures constructed by students at the Laboratory School of Industrial Design (see Figure 7) as an example of how the pedagogical and curricular innovations of the Bauhaus were gradually being introduced in the United States. For the Laboratory, the token inclusion of a sample of student work - although, significantly, not any of the designs of appliances, housewares, or furnishings that had come out of the school —improved the chances that it might tap into new sources of patronage by appropriating some of the museum's prestige. But MoMA also gained from the relationship. Although the museum benefited from a core of wealthy and influential sponsors, during the late 1930s it still struggled to subsist on the diminished flows of private art patronage during the Depression, to overcome stodgy loyalties to Beaux Arts traditions, and to codify its favored varieties of modern art and design as signifiers of elite status and refined taste. It also needed to position itself, however, as an institution within an environment in which public patronage, 


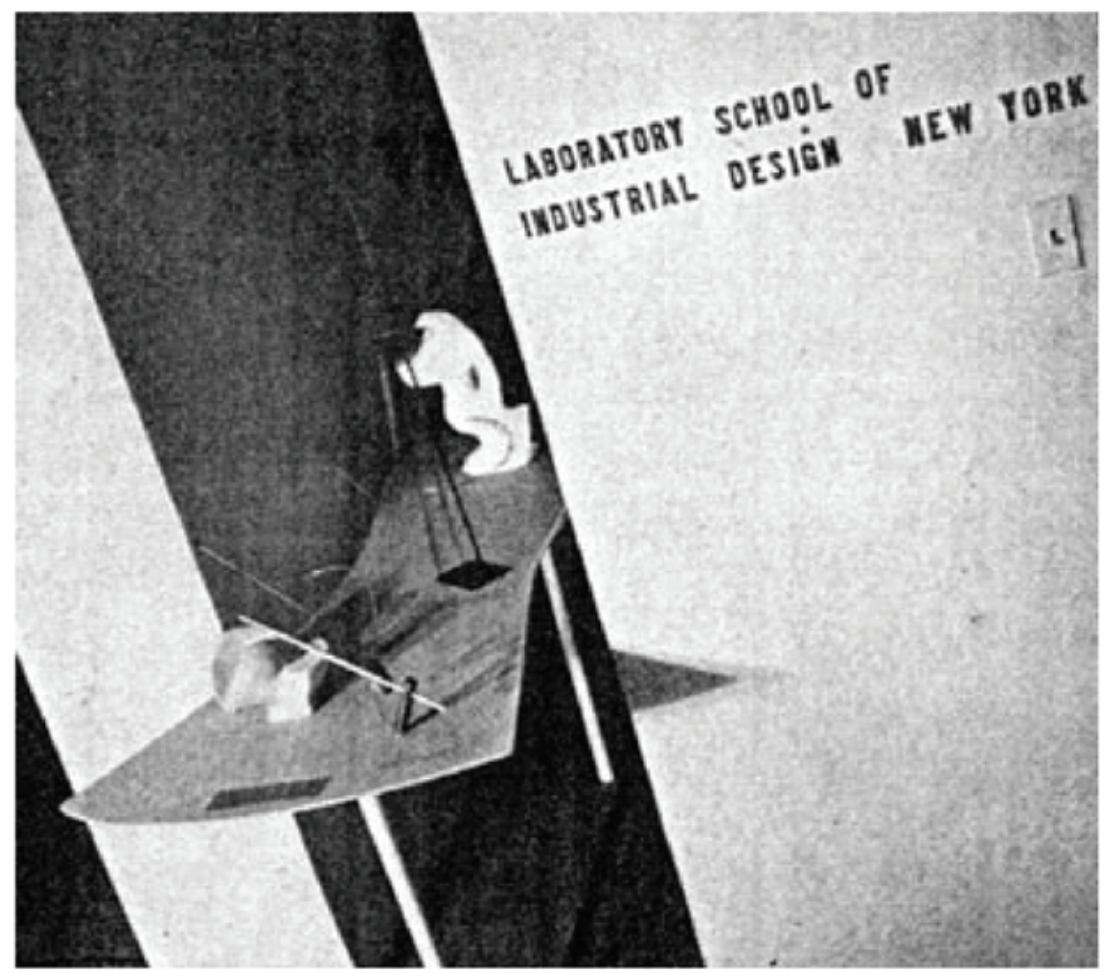

Figure 7: Sculptures by Laboratory students exhibited in the Museum of Modern Art's December 1938 retrospective on the Bauhaus. (Courtesy of MoMA)

while recently curtailed, could experience a resurgence and possibly continue indefinitely. The museum also had to consider the possibility that the cultural initiatives recently launched by the CIO affiliates that organized among New York City's creative class - including the FAECT, the Newspaper Guild, the Book and Magazine Guild, the American Advertising Guild, and United American Artists-might have represented the germination of a new wave of non-profit cultural production rather than the fleeting efflorescence of the Popular Front at its peak. As an independent institution committed to functionalist modernism, albeit one closely associated with the public endeavor of the FAP as well as the ambitions of the CIO unions of cultural workers, the Laboratory clearly served as part of the museum's own front to advance its agenda.

In a caustic review of the Bauhaus show for Architectural Record, Laboratory instructor Levy reiterated many of McCausland's earlier criticisms in an attempt once again to draw a clear distinction between the Laboratory's socially conscious functionalism and what he saw as the museum's formalist modernism that merely imitated the appearance of functionality. Bayer's installation did nothing to transcend the "discrepancy between theory and practice" that separated "Bauhaus ideas and 
principles" from "the work of the Bauhaus itself." Levy chided the Bauhaus masters for their failure to appreciate that "the change from handicraft production to automatic and semi-automatic mass production" entailed "much more than the mere use of simplified forms and novel materials" in designs that were actually ill-suited for mass production and could only be marketed to affluent consumers able to afford craftmade wares. While Levy had a practical appreciation of American mass production that most high modernist aesthetes lacked, the Laboratory's collaborations made it increasingly difficult to render the clear cultural and political judgments that Levy sought. The Laboratory had, after all, sought inclusion in the MoMA show; Bayer, for his part, in March 1939 commenced a two-and-a-half year stint teaching graphics and display design classes for the leftist American Advertising Guild. How was an ordinary person supposed to know if a functionalist poster graphic, coffee pot, chair, or building was intended to signify elite status, or to serve as a harbinger of social democracy ${ }^{34}$

The confusion became even more apparent in the summer of 1939 with the publication of A Design Students' Guide to the New York World's Fair that was jointly produced by the Laboratory and the New York Art Directors' Club. The leading industrial design entrepreneurs of the 1930s created many of the most heavily attended exhibits at the fair, and their version of modernism dominated the look of the "World of Tomorrow." Dreyfuss' agency designed the Democracity exhibit inside the fair's official Theme Center. Bel Geddes' Futurama exhibit for General Motors, which offered visitors weary of the privations of the Depression a tantalizing glimpse of the abundance and technological convenience that supposedly awaited Americans a scant twenty years in the future, proved to be the fair's most visited attraction. Yet the Guide largely ignored these popular lures of the fair, focusing instead on the examples of functionalist architecture and design to be found scattered in the midst of the streamlined pavilions and exhibits. In his introduction to the guide, MoMA curator McAndrew, who had recently joined the Laboratory's Board of Trustees, praised the student contributors for scouring the fair to find examples of "good modern design among the pseudo-modern fantasies." Using language reminiscent of his commentary on the Bauhaus exhibition, he admonished visitors to be wary of the "soft corners and fungoid bulges on the buildings by some of our most celebrated industrial designers" as they gleaned the saving remnants of "honest" modernism "shaped by the exigencies of function and materials" and "free of mannerisms." While the Design Students" Guide upheld the school's aesthetic tenets, it made surprisingly little attempt to present the vetted examples of functionalist design as a coherent set of alternative symbols for the labor left. ${ }^{35}$

The Laboratory's enthusiasts struggled against not only cultural elites' competing claims regarding the significance of functionalist modernism, but also the aesthetic diversity displayed during the 1930s by radical and progressive artists. In recent decades, a renewed appreciation for the modernist endeavors of the Depression-era cultural left—such as the Design Laboratory - has resulted in a reassessment of the harsh judgments rendered previously about the aesthetic proclivities of the Popular Front. Beginning in the late 1930s and continuing with intensifying fervor through 
the first two decades of the Cold War, anti-Stalinist critics and intellectuals frequently tended towards formalist celebrations of modernist art and design as they derided the former partisans of the Popular Front as tasteless philistines wed to an unimaginative social realism. ${ }^{36}$ In actuality, artists and designers who wished to deploy their creativity to further social democratic ends during the 1930s and 1940s utilized a wide variety of aesthetic means - ranging from representational realisms to highly abstracted or surrealist modes of expression - to promote the cause of organized labor and the enactment of permanent public arts projects, widespread public housing, socialized medical care, and racially fair employment practices. This aesthetic heterodoxy in the approaches used by progressive and leftist artists and designers to embed their social values and political aspirations within their cultural production further complicated efforts to popularize the radical connotations of modernism as the 1930s drew towards a close. ${ }^{37}$

The Laboratory faced both the problem of establishing the leftist political meanings of functionalist modernism and the much more pressing problem of keeping the school afloat. The public sector and the white-collar unions had thus far proved inadequate as sponsors. Although the woeful inadequacy of private art patronage during the Depression had initially been a vital catalyst for the cultural initiatives of both the federal government and the labor left, the design school nonetheless drifted back toward conventional avenues of support. In August 1939 with the hopes of putting the Laboratory on the sound financial footing required for its long-term viability as an independent four-year institution, the school's governing committee of faculty and students announced an ambitious new fundraising drive. They set out to solicit from $\$ 25,000$ to $\$ 40,000$ in contributions with which they hoped to pay the school's new director, respected industrial designer George Sakier, improve salaries for the expanded faculty and staff, purchase new shop equipment, and relocate to larger quarters. To kick off the new campaign, the school planned to open a major exhibition of student work on October 12, the same day that Sakier assumed his new post. Prospective donors were invited to a special opening reception. Unfortunately, these events failed to generate sufficient funds for continuation of the school on existing terms, and on November 14 the governing committee suspended formal operations. "You may be sure," wrote the committee, "that among teachers and students there is a group that will not permit the Laboratory School to go out of existence entirely even if the money we need is not received." ${ }^{38}$

Many students and faculty agreed to continue holding classes on an informal basis until the school was able to get back on its feet, but as the year came to a close the prospect of the school surviving grew increasingly dim. In December 1939 much of the Laboratory's shop equipment was auctioned in a court-ordered foreclosure sale. About fifty students and faculty continued to meet into 1940, pinning their hopes on the prospect of organizing another exhibition to raise funds for the school, but by May even this group of die-hard devotees saw the situation as futile. In a final letter to the remaining students, the school's committee announced the Laboratory's demise but assured that their support "was not entirely in vain." The committee noted with due pride that "many of the basic ideas developed by the school during its four years of 
existence have already been incorporated in the teaching methods of other institutions and have certainly influenced the thinking of many individuals now working in the design field." Although conceding that the Laboratory was "technically dead," the committee claimed that much "that was most important of the school stays alive." ${ }^{39}$

To a certain degree, the Design Laboratory succumbed precisely because of its success in promoting modernism. Although modernist pedagogy did not become a new orthodoxy in the United States until after the Second World War, during the late 1930s and early 1940s other schools of art and architecture gradually began to incorporate elements of the Laboratory's pedagogy - minus its emphasis on the radical political and social significance of modern design - into their curricula. Walter Gropius became the dean of the revamped School of Architecture at Harvard in 1936, but modernism made very little headway in many other elite institutions until after World War II. Commercial and applied art programs at Pratt Institute and Carnegie Tech had launched their first courses in "industrial design" in 1934 and 1935, but these schools only began to incorporate modernist techniques substantively between 1938 and 1941. Laszlo Moholy-Nagy, who supervised the Foundations course at the Bauhaus in the 1920s, established the Institute of Design in Chicago in the fall of 1937 with the backing of the retailer Marshall Field - who also financed the progressive New York tabloid newspaper $P M$ during the 1940 s — and packaging magnate Walter Paepcke - who funded the Aspen Institute in the 1950s. Even the patronage of these two important business figures proved inadequate to sustain Moholy-Nagy's "New Bauhaus," which shut its doors for lack of funds in 1938 and only operated sporadically until it was absorbed by the Illinois Institute of Technology in the mid-1940s. At many schools where they later taught, former Laboratory faculty made important contributions to the development of modernist curricula. I. Rice Pereira, for instance, brought the Design Synthesis course to Pratt during the 1940s. William Friedman brought his expertise to the University of Iowa and the University of Minnesota before he and his wife, former Laboratory instructor Hilde Reiss, joined the Walker Art Center in Minneapolis, where they launched a series of successful Everyday Art design exhibitions in the late 1940s and the accompanying publication Everyday Art Quarterly. William Priestly eventually rejoined his mentor Mies van der Rohe as well as Herbert Bayer at the Illinois Institute of Technology in Chicago, where all three built upon the foundation laid by Moholy-Nagy's Institute of Design. Paul Rand went on to become a leading design educator at Yale while continuing to work as one of America's most prolific commercial graphic artists, creating iconic logos for firms such as the American Broadcasting Company (ABC), Westinghouse, and International Business Machines (IBM) ${ }^{40}$

While the Design Laboratory's crucial, if often overlooked, contribution to the development of modernist visual and material culture in the United States clearly demonstrates its aesthetic legacy, its political and social legacy is largely one of unrealized possibilities. For the school's advocates, the struggle to sustain the Laboratory and to expand its influence was not just about propagating good taste, but rather about promoting autonomy for those who earned a living through their creative mental labor in the culture industries and using the designs they produced as a way of encouraging 
greater autonomy for the masses of American workers and consumers. The leftist social movements capable of reviving an institution like the Laboratory or employing its designs as intended remained vibrant through the Second World War and into the immediate postwar period. The final demise of the WPA in the early 1940s undercut the most important means of public patronage, but other governmental initiatives, such as the wartime propaganda campaigns of the Office of Price Administration (OPA) or the generic "Victory" models of certain household appliances approved by the War Production Board (WPB) and designed to minimize the utilization of scarce materials, furnished some new opportunities. The termination of these public programs, and the failure of efforts by progressive unions to promote consumer cooperatives, however, eliminated in the postwar years the means for sponsoring the autonomous production of modernist design as well as any feasible avenue for achieving social democratic ends. By the 1950s and 1960s, successful Laboratory alumni like interior designer Suzanne Sekey and furniture and housewares designer Don Wallance who wished to adhere to their ideals of creative autonomy and artistic integrity found few chances of doing so outside of designing for limited market segments of affluent customers. ${ }^{41}$

The crisis of the Great Depression had seriously compromised the culture of consumer capitalism that had developed in the United States during the early twentieth century, and the reinstitution of corporate hegemony after World War II greatly diminished the chances to establish alternative cultural institutions like the Design Laboratory. A new round of recent shocks, however, has destabilized key elements of American consumer capitalism and increased the relevance of the Laboratory as an historical example. The Laboratory's critique of the wastefulness of American consumerism, rooted in Depression-era notions that the nation's economy had attained a level of "maturity" in which growth would be modest and natural resources would have to be carefully managed, should resonate with those who aspire to promote "green" consumption by making ecological sustainability the guiding principle of the design process. Furthermore, at no time since the Depression have the prevailing modes of advertising and advertising-supported media that have largely defined American consumer capitalism appeared on shakier ground. The weakening of consumer demand during the "Great Recession" at the end of the first decade of the twenty-first century has combined with the proliferation of new media outlets to call into question the viability of many longstanding cultural enterprises that have been dependent on advertising revenue. The turmoil has in turn resulted in a wave of layoffs in the culture industries and in widespread insecurity for those members of the creative class who have kept their jobs. While it seems unlikely that there will be a major new program for the public production of culture on a par with the Federal Art Project given the political climate and the fiscal constraints of the 2010s, the contemporary crisis of the culture industries could provide new opportunities to launch cooperative or non-profit institutions along the lines of the Design Laboratory. Despite its brief existence, the Laboratory offers an important model for participatory institutions to generate democratic solutions in the twenty-first century. 


\section{Notes}

1. "Design Laboratory" Brochure, December 1935, Records of the Federal Art Project of the Works Progress Administration, Archives of American Art, Smithsonian Institution, Washington, DC (hereafter FAP), reel DC60, frames 563-65. The original documents in this collection are located in the Records of the Works Progress Administration, Records Group 69, National Archives and Records Administration, College Park, MD.

2. "WPA Establishes Free Art School," New York Times, December 2, 1935, 19; and Frances Pollak to Holger Cahill, December 5, 1935, Francis V. O’Connor Collection, Archives of American Art, Smithsonian Institution, Washington, DC (hereafter FO), reel 1084, frame 180. The original documents in this collection are located in the Records of the Works Progress Administration, Records Group 69, National Archives and Records Administration, College Park, MD.

3. On the broader context of the cultural and political ferment of the 1930s in which the Design Laboratory and other FAP initiatives operated, see Richard D. McKinzie, The New Deal for Artists, (Princeton: Princeton University Press, 1973), 21-148; Michael Denning, The Cultural Front: The Laboring of American Culture in the Twentieth Century, (New York: Verso, 1996), 38-83, 151-59; Bruce Bustard, ed., A New Deal for the Arts, (Washington, DC: National Archives and Records Administration in association with University of Washington Press, 1997), 1-20, 85-121; Susan Noyes Platt, Art and Politics in the 1930s: Modernism, Marxism, and Americanism, (New York: Midmarch Arts Press, 1999), 173-92; Andrew Hemingway, Artists on the Left: American Artists and the Communist Movement, 1926-1956, (New Haven: Yale University Press, 2002), 75-100, 147-88; and A. Joan Saab, For the Millions: American Art and Culture Between the Wars, (Philadelphia: University of Pennsylvania Press, 2004), 15-53.

4. Don Wallance to Charles Hublitz, February 6, 1980, Donald Wallance Collection, Dreyfuss Research Center, Cooper-Hewitt National Design Museum, New York, NY (hereafter DW), Biographical Materials, Box 1, "Biographical Statements, Questionnaires, and Related Materials" folder.

5. On the early connections between modernist aesthetics and political and cultural radicalism, see Martin Green, New York, 1913: The Armory Show and the Paterson Strike Pageant, (New York: Scribner, 1988), 9-61, 74-86, 129-91; and John Loughery, John Sloan: Painter and Rebel, (New York: Henry Holt, 1995), 169-247.

6. On the early efforts by some merchants and advertisers to deploy modernism in the service of consumer capitalism prior to the Depression, see Jeffrey Meikle, Twentieth Century Limited: Industrial Design in America, 1925-1939, (Philadelphia: Temple University Press, 1979), 7-38; Arthur J. Pulos, American Design Ethic: A History of American Industrial Design to 1940,(Cambridge: MIT Press, 1983), 272-333; Roland Marchand, Advertising the American Dream: Making Way for Modernity, (Berkeley: University of California Press, 1985), ; Michele H. Bogart, Artists, Advertising, and the Borders of Art, (Chicago: University of Chicago Press, 1995), 137-43, 221-25.

7. On the founding of the Museum of Modern Art and the emergence of elite patronage and institutional support for modernism, see Russell Lynes, The Good Old Modern: An Intimate Portrait of the Museum of Modern Art, (New York: Atheneum, 1973), 57-211; William B. Scott and Peter M. Rutkoff, New York Modern: The Arts and the City, (Baltimore: Johns Hopkins University Press, 1999), 163-93; Platt, Art and Politics in the 1930s, 202-05; and Sybil Gordon Kantor, Alfred H. Barr and the Intellectual Origins of the Museum of Modern Art, (Cambridge: MIT Press, 2002), 242-353; and Saab, For the Millions, 84-128.

8. On the emergence of the industrial design profession during the late 1920 s and 1930 s, the development of the streamlined style of modern design, and corporate America's embrace of streamlining, see Meikle, Twentieth Century Limited, 39-133; Pulos, American Design Ethic, 337-423; David E. Nye, Electrifying America: Social Meanings of a New Technology, 1890-1940, (Cambridge: MIT Press, 1990), 339-80; Roland Marchand, "The Designers Go to the Fair: Walter Dorwin Teague and the Professionalization of Corporate Industrial Exhibits, 1933-1940," Design Issues 8 (Autumn 1991): 4-17; Marchand, "The Designers Go to the Fair II: Norman Bel Geddes, The General Motors 'Futurama,' and the Visit to the Factory Transformed," Design Issues 8 (Spring 1992): 23-40; Terry Smith, Making the Modern: Industry, Art, and Design in America, (Chicago: University of Chicago Press, 1993), 353-83, 405-21; David Gartman, Auto Opium: A Social History of American Automobile Design, (New York: Routledge, 1994), 100-35; Shelley Nickles, "Preserving Women': Refrigerator Design as a Social Process in the 1930s," Technology and Culture 43 (October 2002): 693-727; and Christina Cogdell, Eugenic Design: Streamlining America in the 1930s, (Philadelphia: University of Pennsylvania Press, 2004), 33-83.

9. On the consumers' activists of the $1930 \mathrm{~s}$, and their resistance to the marketing ploys of American business, see Lawrence Glickman, "The Strike in the Temple of Consumption: Consumer Activism and Twentieth-Century American Political Culture," Journal of American History 88 (June 2001): 99-128; Lizabeth Cohen, A Consumers' Republic: The Politics of Mass Consumption in Postwar America, (New York: Knopf, 2003), 18-53, 63-109; Meg Jacobs, Pocketbook Politics: Economic Citizenship in Twentieth-Century America, (Princeton: Princeton University Press, 2004), 122-35, 150-64, 180-220; Kathy Newman, Radio Active: Advertising and Consumer Activism, 1935-1947, (Berkeley: University of California Press, 2004), 52-77, 92-108, 145-65; Charles F. McGovern, Sold American: Consumption and Citizenship, 1890-1945, (Chapel Hill: University of North Carolina Press, 2006), 186-204, 241-53, 302-13, 327-33; Inger Stole, Advertising on Trial: Consumer Activism and Corporate Public Relations 
in the 1930s, (Urbana: University of Illinois Press, 2006), 21-105; and Daniel Scroop, "The Anti-Chain Store Movement and the Politics of Consumption," American Quarterly 60 (December 2008): 925-49.

10. On the efforts of some cultural elites to establish an "International Style" of functionalist modernism, see Smith, Making the Modern, 385-404; Serge Henry Matthews, "The Promotion of Modern Architecture by the Museum of Modern Art in the 1930s," Journal of Design History 7 (1994): 43-59; Barbara Staniszewski, The Power of Display: A History of Exhibition Installations at the Museum of Modern Art, (Cambridge: MIT Press, 1998), 143-90; and Margaret Kentgens-Craig, The Bauhaus and America: First Contacts, 1919-1936, (Cambridge: MIT Press, 1999), 74-79, 139, 144, 158-66.183-92.

11. Cahill, "Industrial Design Education" (undated speech typescript), Holger Cahill Papers, Archives of American Art, Smithsonian Institution, Washington, DC (hereafter HC), reel 5291. On Cahill and his experiences as a journalist, curator, and administrator, see Wendy Jeffers, "Holger Cahill and American Art," Archives of American Art Journal 31, no. 4 (1991), 2-11; Platt, Art and Politics in the 1930s, 177-80, 205-06; Hemingway, Artists on the Left, 79, 81, 84, 151-53; and Saab, Art for the Millions, 20-23.

12. Pollak to Cahill, October 22, 1935, FAP, reel DC91; Cahill to Bruce McClure, November 2, 1935, HC, reel NDA15, frame 377; Cahill to Pollak, November 18, 1935, FAP, reel DC91. On Rohde's work as a furniture designer, see Phyllis Ross, "Merchandising the Modern: Gilbert Rohde at Herman Miller," Journal of Design History 17 (2004): 359-76.

13. Pollak to Cahill, December 5, 1935, FO, reel 1084, frames 181-83; Thorstein Veblen, The Theory of the Leisure Class: An Economic Study of Institutions (orig. 1899; reprint, New York: Random House, 1934), 157, 162, 244; and Veblen, "Arts and Crafts," Journal of Political Economy 11 (December 1902): 108-111. On Veblen's importance in American social thought, see Dorothy Ross, The Origins of American Social Science, (New York: Cambridge University Press, 1991), 204-15; Martha Banta, Taylored Lives: Narrative Productions in the Age of Taylor, Veblen, and Ford, (Chicago: University of Chicago Press, 1993), 91-92; John Jordan, Machine-Age Ideology: Social Engineering and American Liberalism, 19111939, (Chapel Hill: University of North Carolina Press, 1994), 14-19; Platt, Art and Politics in the 1930s, 32-33; and Howard Brick, Transcending Capitalism: Visions of a New Society in Modern American Thought, (Ithaca: Cornell University Press, 2006), 47-49, 63-65.

14. Lewis Mumford, Technics and Civilization, (New York: Harcourt, Brace and Co., 1934), 5-6, 345-55, 429. On Mumford's influence during the 1930s, see Casey N. Blake, Beloved Community: The Cultural Criticism of Randolph Bourne, Van Wyck Brooks, Waldo Frank, and Lewis Mumford, (Chapel Hill: University of North Carolina Press, 1990), 278-95; Jordan, Machine-Age Ideology, 255-61; and Platt, Art and Politics in the 1930s, 33-35.

15. Cahill to Frances Pollak, September 18, 1935, FO, reel 1084, frame 46; "American Bauhaus," Architectural Forum, January 1936, 17, 34; "Design Laboratory, New York" American Magazine of Art, February 1936, 117; "Classes at Capacity in WPA Art School," New York Times, April 17, 1936, 5; Federal Project Number One, "Supervising Employees on Project Unit Payroll," August 1, 1936, FO, reel 1084, frame 715-16; "Federation Technical School Design Laboratory, Catalog of Courses, 1937-1938", DW, Biographical Materials, Box 1, "Education-Design Laboratory, Circulars, 1936-1940" folder. For an interesting take on the problems of integrating "industrial" and "artistic" training in design education in the early 1900s, see Barbara Jaffee, "Before the New Bauhaus: From Industrial Drawing to Art and Design Education in Chicago," Design Issues 21 (Winter 2005): 41-62.

16. Cahill to Bruce McClure, November 2, 1935, HC, reel NDA15, frame 377; Cahill to Jacob Baker, February 13, 1936, FAP, reel DC54, frames 221-22.

17. Cahill to Henry I. Brock, HC, January 29, 1936, reel NDA15, frame 379; and Works Progress Administration, "Holger Cahill Reports on Progress of Federal Art Program," February 16, 1936, FAP, reel DC46, frames 31-32. For more on the index, please see Virginia Tuttle Clayton, "Picturing a 'Usable Past," in Clayton, Elisabeth Stillinger, Erika Doss, Deborah Chotner, eds., Drawing on America 's Past: Folk Art, Modernism, and the Index of American Design, (Washington, DC and Chapel Hill: National Gallery of Art/University of North Carolina Press, 2002), 1-43; and Doss, "American Folk Art's 'Distinctive Character': The Index of American Design and New Deal Notions of Cultural Nationalism," in Drawing on America's Past, 61-73. On the antiquarian and antimodernist counter-current in the appreciation of American decorative and applied arts during this period, see Thomas Denenberg, Wallace Nutting and the Invention of Old America, (New Haven: Yale University Press, 2003), 1-21, 87-151, 185-93.

18. Baker to Harry Hopkins, February 14, 1936, HC, reel 5285, frame 953; Cahill to Pollak, February 13, 1936, FAP, reel DC48, frame 201; Ruth Reeves to Cahill, June 1, 1936, FAP, reel DC52, frames 552-54.

19. WPA, "Design Laboratory," August 22, 1936, Elizabeth McCausland Papers, Archives of American Art, Smithsonian Institution, Washington, DC (hereafter EM), reel D374, frames 374-78.

20. Ibid.; Gilbert Rohde, "The Design Laboratory," American Magazine of Art, October 1936, 63843, 686; Also see Jacqueline A. Keyes, "WPA Educators Blazing Trail with School in Industry Design," New York Times, October 25, 1936, II, 5, for more phrasing that, as with the essay signed by Rohde, appears to have been lifted from FAP publicity copy. For a different interpretation of this phase of the laboratory's history, particularly the significance of the school's commitment to modernism, see Karen A. Bearor, "The Design Laboratory: New Deal Experiment in Self-Conscious Vanguardism," Southeastern College Art Conference Review 13 (1996): 14-31. 


\section{Shannan Clark}

21. William Friedman, "Book Review: An Enquiry Into Industrial Art in England, by Nikolaus Pevsner," PM, December 1937, 59-60. In June 1940 when the progressive tabloid newspaper PM began publication in New York City, the Art Directors' Club changed the name of its cooperatively produced journal to $A-D$ to avoid confusion.

22. Thorstein Veblen, The Higher Learning in America: A Memorandum on the Conduct of Universities by Business Men (orig. 1918; reprint New York: Sentry Press, 1965), 31.

23. American Student Designer, May 19, 1936, 1-3, DW, Biographical Materials, Box 1, "Education - Design Laboratory, Student Activities, 1936-1940" folder; Lawrence Drake to Harry Hopkins, March 21, 1936, FO, reel 1086, frame 449; Reeves to Cahill, June 17, 1936, FAP, reel DC52, frame 564; Edith Halpert to Cahill and Thomas Parker, July 26, 1936, FAP, reel DC52, frames 99-103; Pollak to Audrey McMahon, August 4, 1936, FO, reel 1085, frame 841; McMahon to Cahill, August 10, 1936, FO, reel 1085, frame 840; E.M. Benson to Thomas Parker, November 4, 1936, FAP, reel DC54, frame 284; "Plan WPA Work Stoppage," New York Times, December 1, 1936, 5; "WPA Art Executives Warned on Job Cuts," New York Times, December 1, 1936, 6; "WPA Artists Fight Police; 219 Ejected, Many Clubbed," New York Times, December 2, 1936, 1, 16; "Mayor Seeks to End Lay-Offs on WPA," New York Times, December 3, 1936, 4; Josiah Marvel to Hopkins, December 4, 1936, FAP, reel DC47, frame 73; Marvel to Henry Morgenthau, December 4, 1936, FO, reel 1085, frame 845; Parker to McMahon, December 12, 1936, FAP, reel DC47, frame 72; McMahon to Parker, December 15, 1936, FAP, reel DC47, frame 70; Marvel to McMahon, December 16, 1936, FAP, reel DC47, frame 71; McMahon to Cahill, December 18, 1936, FO, reel 1085, frame 854; McMahon to Cahill, December 21, 1936, FAP, reel DC47, frame 84; Parker to McMahon, December 23, 1936, FAP, reel DC47, frame 69; Benson to Parker, February 17, 1937, FAP, reel DC54, frame 294; "25 Strikes Called in WPA Here Today," New York Times, March 31, 1937, 8; "WPA Ready to Drop 2,500 in Next Week," New York Times, April 15, 1937, 14.

24. "Sit-In at Art Project," New York Times, May 15, 1937, 8; "WPA Stoppage Due to Involve 20,000," New York Times, May 27, 1937, 2; “10,000 Stop Work on WPA Projects," New York Times, May 28, 1937, 1, 12; "WPA Notifies 1,709 of Dismissal Here," New York Times, June 22, 1937, 26; "WPA Here to Drop 12,000 Next Week," New York Times, June 23, 1937, 1, 6; Milton Kalish to Suzanne Sekey, undated letter in Shannan Clark's possession (although clearly from May or June 1937); Milton Lowenthal to Dean Brimhall, June 21, 1937, FAP, reel DC92; McMahon to Cahill, June 25, 1937, FAP, reel DC47, frame 164; "WPAArt School Goes On," New York Times, July 4, 1937, 2; Lowenthal to McMahon, FAP, July 7, 1937, reel DC92; Cahill to Lowenthal, July 10, 1937, FAP, reel DC92; Parker to McMahon, July 10, 1937, FAP, reel DC47, frame 163; Parker to McMahon, July 27, 1937, FAP, reel DC92; Design Laboratory Brochure, Summer 1937, DW, Biographical Materials, Box 1, "Education-Design Laboratory, Circulars, 1936-1940" folder; "Design Laboratory Catalogue of Courses, 1937-1938," 14, DW, Biographical Materials, Box 1, "Education - Design Laboratory, Circulars, 1936-1940" folder; Interview with William Friedman by Mary McChesney, June 16, 1965, A New Deal for Artists Interview Series, Archives of American Art, Smithsonian Institution, 6; Interview with Jack Kufeld by Avis Berman, October 5, 1981, Mark Rothko and His Times Oral History Project, Archives of American Art, Smithsonian Institution, 14.

25. Charmion von Wiegand, "The Fine Arts," New Masses, July 6, 1937, 30-31; Liame Dunne, "Learning Design and Production: The Methods Used in the Design Laboratory of the F.A.E.C.T. School," PM, August 1937, 39-44; "Chapter School Grows in Influence," Technical America (FAECT monthly journal), September 1937, 10; "Design Laboratory Catalogue of Courses, 1937-1938," 14; "Design Laboratory at FAECT," Architectural Record, October 1937, 41; "Design Laboratory," Design, November 1937, VII.

26. "Design Laboratory Catalogue of Courses, 1937-1938," 5-6; Elizabeth McCausland, "An 'American Bauhaus': Design Laboratory on Permanent Basis," Springfield Union and Republican, August 22, 1937, 6E.

27. On the ACA show see "Laboratory Design Project Show at the A.C.A.," New York Times, August 15, 1937, X, 7; "Design Laboratory Exhibition, August 9th to 22nd, A.C.A. Gallery," EM, reel D375, frames 334-38; McCausland, "An 'American Bauhaus'.” On Grossman, se "The Treasurer and the Figure She Cuts," Guild News (Book and Magazine Guild publication), January 1941, 3.

28. Ephemera, including invitations and flyers for various Design Laboratory events from 1937 through 1939 in DW, Biographical Materials, Box 1, "Education-Design Laboratory, Student Activities, 1936-1940” folder. Also see “Robot “38 Rocks $16^{\text {th }}$ Street," Design Laboratory Perspective, January 1938, 3, DW, Biographical Materials, Box 1, "Education-Design Laboratory, Student Activities, 1936-1940" folder; "Council of Industrial Designers," Design Laboratory Perspective, January 1938, 6.

29. "Student Responsibilities,” Design Laboratory Perspective, January 1938, 1; Jacques F. Levy, "From a Faculty Member," Design Laboratory Perspective, January 1938, 2.

30. See "Laboratory School of Industrial Design Provisional Charter," EM, reel D384G, frames 970-977. On the activities of the Rapp-Coudert Committee, see Ellen Schrecker, Many Are the Crimes: McCarthyism in America, (Princeton: Princeton University Press, 1998), 97.

31. Levy, Curriculum Vitae, February 1941, DW, Biographical Materials, Box 1, "Education—Design Laboratory, Correspondence, Announcements, Related Materials, 1934-1942” folder; Laboratory School of Industrial Design (LSID), "New Appointments to the Faculty for Spring 1939," DW, Biographical Materials, Box 1, "Education-Design Laboratory, Correspondence, Announcements, Related Materials, 1934-1942” folder; LSID, “1939 Bulletin,” DW, Biographical Materials, Box 1, "Education—Design 
Laboratory, Circulars, 1936-1940” folder; LSID, "Spring 1939 Course Listings," EM, reel D375, frames 328-33; LSID, "Exhibit by 9 Instructors Recently Appointed to the Faculty of their Professional Work in Industrial Design and Graphic Arts," EM, reel D375, frames 317-18; LSID, "Instructors for Basic Courses, Fall 1939-40," and "Notes for course on 'Cultural Morphology,' Laboratory School of Industrial Design, 1939," EM, reel D384G.

32. "Paul Rand," PM, October 1938, 1-16; McCausland, "Cultural Morphology I-Syllabus," and "Notes for course on 'Cultural Morphology,' Laboratory School of Industrial Design, 1939," EM, reel D384G; Interview with Suzanne Sekey by Shannan Clark, May 30, 2003. For more on McCausland, also see Platt, Art and Politics in the 1930s, 65-79.

33. John McAndrew, "'Modernistic' and 'Streamlined'," The Bulletin of the Museum of Modern Art, December 1938, 2.

34. Levy, "Bauhaus and Design, 1919-1939," Architectural Record, January 1939, 71, 118. For more sympathetic views from the left, see "Bauhaus," Direction, December 1938, 23; and "Bauhaus Revived," U.A.A Commercial Artists Bulletin, March 1939, 1, Rockwell Kent Papers, Archives of American Art, Smithsonian Institution, Washington DC (hereafter RK), reel 5242, frame 702. For more about Bayer's teaching for the Ad Guild between March 1939 and December 1941, see United Office and Professional Workers Greater New York Joint Council, "Special Series of Forums for those in the Art, Advertising, and Publishing Fields," RK, reel 5242, frame 717; "Famous Ad Man Teaches Guild," Office and Professional News, March 1940, 5; and "Herbert Bayer's Design Class," A-D, June 1941, 18-30.

35. A Design Students' Guide to the New York World's Fair, compiled for P/M Magazine by the Laboratory School of Industrial Design, (New York: Laboratory School of Industrial Design, 1939), DW, Biographical Materials, Box 1.

36. Among the foundational statements of the anti-Stalinist intellectuals' aesthetic critique of the cultural products of the Popular Front were Clement Greenberg, "Avant-Garde and Kitsch," Partisan Review 6 (Fall 1939): 34-49; and Dwight Macdonald, “A Theory of Popular Culture,” politics, February 1944, 20-23. Also see Richard Pells, The Liberal Mind in a Conservative Age: American Intellectuals in the 1940s and 1950s, (New York: Harper and Row, 1985), 217, 224, 276, 278-79, 303; Serge Guilbaut, How New York Stole the Idea of Modern Art: Abstract Expressionism, Freedom, and the Cold War, Arthur Goldhammer trans., (Chicago: University of Chicago Press, 1983), 17-99; Alan Wald, The New York Intellectuals: The Rise and Decline of the Anti-Stalinist Left from the 1930s to the 1980s, (Chapel Hill: University of North Carolina Press, 1987), 207-08, 217-23; Andrew Ross, No Respect: Intellectuals and Popular Culture, (New York: Routledge, 1989), 15-16, 21-23, 31, 42-64; and Denning, Cultural Front, 107-10.

37. On the absence of a consistent aesthetic strategy even among those artists most self-consciously identified with the movements for radical social transformation in the 1930s, see Denning, Cultural Front, 115-23; Platt, Art in the 1930s, 87-101, 147-65; and Hemingway, Artists on the Left, 1-4, 102-46, 169-88.

38. "LSID Report to the General Membership," August 22, 1939, DW, Biographical Materials, Box 1, "Education - Design Laboratory, Correspondence, Announcements, Related Materials, 1934-1942" folder; 1; Memorandum to All Students, LSID, November 14, 1939, DW, Biographical Materials, Box 1, "Education - Design Laboratory, Correspondence, Announcements, Related Materials, 1934-1942" folder.

39. Receipt of Foreclosure Sale, First District Court, Borough of Manhattan, December 8, 1939, DW, Biographical Materials, Box 1, "Education-Design Laboratory, Correspondence, Announcements, Related Materials, 1934-1942" folder; Minutes of Student Committee, LSID, December 27, 1939, DW, Biographical Materials, Box 1, "Education-Design Laboratory, Correspondence, Announcements, Related Materials, 1934-1942" folder; Anna Bogue, William C. Whitney Foundation, to Frances T. Schwab, May 24, 1940, DW, Biographical Materials, Box 1, "Education-Design Laboratory, Correspondence, Announcements, Related Materials, 1934-1942" folder; Student Committee of Laboratory School of Industrial Design to students, June 6, 1940, DW, Biographical Materials, Box 1, "Education-Design Laboratory, Correspondence, Announcements, Related Materials, 1934-1942” folder.

40. On Moholy-Nagy's Institute of Design in Chicago, see "Bauhaus Will Open In Chicago in Fall," New York Times, August 22, 1937, II, 6; "Gropius Aide Here to Run Art School," New York Times, September 2, 1937, 23; "Chicago's New Bauhaus," New York Times, September 12, 1937, XI, 7; "The New Bauhaus," Architectural Forum, October 1937, 22, 82. Also see James Sloan Allen, The Romance of Commerce and Culture: Capitalism, Modernism, and the Chicago-Aspen Crusade for Cultural Reform, (Chicago: University of Chicago Press, 1983), 3-77. On the early years of the industrial design programs at Carnegie and Pratt, see Peter Müller-Munk, "Industrial Design," Design, January 1939, 1215; and Alexander J. Kostellow, "Design and Structure Program of the Pratt Institute Art School," Design, May 1940, 6-9, 24. On Pereira at Pratt, see Pereira, undated c.v., "Personal Documents and Biographical Information," Irene Rice Pereira Papers, Archives of American Art, Smithsonian Institution., Washington, DC, reel 1296. On Friedman and Reiss at the Walker Art Center, see Hilde Reiss to McCausland, October 25, 1945, EM, reel D371, frames 1126-28; Friedman to McCausland, January 21, 1946, EM, reel D371, frame 1148. On Rand's subsequent career, see From Lascaux to Brooklyn, (New Haven: Yale University Press, 1996); Jessica Helfand, Paul Rand: American Modernist, (New York: William Drenttel, 1998); and Steven Heller, Paul Rand, (New York, NY: Phaidon, 2000).

41. Wallance used his own flatware designs for H.E. Lauffer Co. during the 1950s as an example of the "independent craftsman" type of design in Wallance, Shaping America's Products, (New York: Reinhold, 1956), 118-22. 
